University of Nebraska - Lincoln

DigitalCommons@University of Nebraska - Lincoln

\title{
Opportunities for improving risk communication during the permitting process for entomophagous biological control agents: a review of current systems
}

Oulimathe Paraiso

Florida Agricultural and Mechanical University,, oparaiso@ufl.edu

M. Kairo

Florida Agricultural and Mechanical University, moses.kairo@famu.edu

N. C. Leppla

University of Florida, ncleppla@ufl.edu

J. P. Cuda

University of Florida, jcuda@ufl.edu

M. Owens

Florida Agricultural \& Mechanical University, marcia.owens@famu.edu

See next page for additional authors

Follow this and additional works at: https://digitalcommons.unl.edu/usdaarsfacpub

Paraiso, Oulimathe; Kairo, M.; Leppla, N. C.; Cuda, J. P.; Owens, M.; Olexa, M. T.; and Hight, S. D., "Opportunities for improving risk communication during the permitting process for entomophagous biological control agents: a review of current systems" (2012). Publications from USDA-ARS / UNL Faculty. 1420.

https://digitalcommons.unl.edu/usdaarsfacpub/1420

This Article is brought to you for free and open access by the U.S. Department of Agriculture: Agricultural Research Service, Lincoln, Nebraska at DigitalCommons@University of Nebraska - Lincoln. It has been accepted for inclusion in Publications from USDA-ARS / UNL Faculty by an authorized administrator of DigitalCommons@University of Nebraska - Lincoln. 


\section{Authors}

Oulimathe Paraiso, M. Kairo, N. C. Leppla, J. P. Cuda, M. Owens, M. T. Olexa, and S. D. Hight 


\title{
Opportunities for improving risk communication during the permitting process for entomophagous biological control agents: a review of current systems
}

\author{
Oulimathe Paraiso $\cdot$ M. T. K. Kairo •
}

S. D. Hight $\cdot$ N. C. Leppla $\cdot$ J. P. Cuda $\cdot$

M. Owens $\cdot$ M. T. Olexa

Received: 19 May 2011/Accepted: 3 June 2012/Published online: 20 June 2012

(C) International Organization for Biological Control (IOBC) 2012

\begin{abstract}
Concerns about potentially irreversible non-target impacts from the importation and release of entomophagous biological control agents (BCAs) have resulted in increasingly stringent national import requirements by National Plant Protection Organizations worldwide. However, there is a divergence of opinions among regulators, researchers, environmentalists, and the general public on ways to appropriately manage associated risks. Implementation of a comprehensive and effective risk communication process might narrow the opinion gaps. Results from a
\end{abstract}

Handling Editor: Dirk Babendreier

O. Paraiso $(\bowtie)$

Center for Biological Control, College of Agriculture and Food Sciences, Florida Agricultural and Mechanical University, 1740 Martin Luther King Boulevard,

Perry-Paige Building, Room 308 (South), Tallahassee, FL 32307, USA

e-mail: oparaiso@ufl.edu

M. T. K. Kairo

Center for Biological Control, College of Agriculture and Food Sciences, Florida Agricultural and Mechanical University, 1740 Martin Luther King Boulevard,

Perry-Paige Building, Room 310 (South), Tallahassee, FL 32307, USA

e-mail: moses.kairo@famu.edu

S. D. Hight

USDA-ARS-Center for Medical Agricultural and Medical Entomology, 6383 Mahan Drive, Tallahassee,

FL 32308, USA

e-mail: stephen.hight@ars.usda.gov comprehensive survey conducted in the United States were used to describe communication habits of stakeholders involved in biological control and identify areas that are fundamental in an efficient process. In addition, this study critically reviews risk communication practices and how phytosanitary decisions are communicated in the permitting systems for entomophagous BCAs of several countries to identify risk communication tools used in an effective risk communication framework. The following barriers to efficient risk communication were identified: absence of a formalized risk communication process, undefined risk communication goals and target audiences,

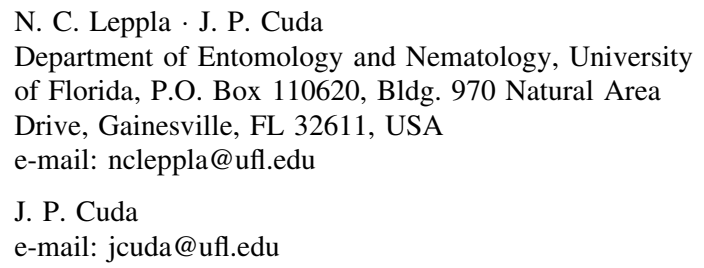

M. Owens

Environmental Sciences Institute, Florida Agricultural \& Mechanical University, 1515 Martin Luther King Boulevard, Tallahassee, FL 32307, USA

e-mail: marcia.owens@famu.edu

M. T. Olexa

Food and Resource Economics Department, IFAS, University of Florida, 2126 MCCB, P.O. Box 110240, Gainesville, FL 32611, USA

e-mail: olexa@ufl.edu 
lack of credibility and objectivity of information sources, inefficiency of mode of distribution of messages, insufficient public participation, and lack of transparency of decision making processes. This paper suggests the creation and/or enhancement of modes of distribution of risk messages to increase coverage, understanding, and guidance. For instance, messages should be presented in different formats such as internet, brochures, and newspapers. Surveys, public meetings, and trainings/workshops are tools that can be used to characterize stakeholders' diversity and develop risk messages specific to the targeted audience. Implementation of a participatory decision making process will increase stakeholder involvement and trust in the risk management plan. Development of practical mechanisms, such as public hearings will increase all stakeholders' involvement in the risk assessment process. A clear framework describing how public comments will be incorporated in the decision making process should be implemented. Finally, to ensure a streamlined risk communication process, there must be consistency in the messages disseminated by federal, state, and local agencies.

Keywords Biological control · Survey

questionnaire - Pest risk analysis - Risk assessment . Risk communication $\cdot$ Permitting process

\section{Introduction}

Classical biological control is often a key component in invasive species management programs, and during the last Century, many successful programs using entomophagous natural enemies have been reported (van Lenteren et al. 2006). However, once introduced and established, biological control agents (BCAs) are almost impossible to eradicate (Simberloff and Stiling 1996; van Lenteren et al. 2006). Therefore, phytosanitary decisions during the permitting process of new BCAs must take into account the likelihood of occurrence and consequences of possible non-target effects. The potential for negative impacts from introducing a BCA are assessed by conducting a risk analysis. At the international level, this process is based on International Standards for Phytosanitary Measures (ISPMs) developed by the International Plant Protection Convention (IPPC) ( 2004, 2005, 2007). Additionally, several regional country blocks and/or individual countries have developed their own guidelines and/or legislation to address the issue of risk before the importation and environmental release of biological control organisms (Australia Quarantine Inspection Service (AQIS) 1997; Barratt and Moeed 2005; Environmental Risk Management Authority) (ERMA) 2012; Mason et al. 2005; North American Plant Protection Organization (NAPPO) 2008). These various international, regional, and national instruments identify risk communication as an integral activity that occurs continuously during the entire biological control process (Chartier and Gabler 2001; ERMA 2012; Hunt et al. 2008; IRA 2007).

Risk communication has been addressed by different schools of thought. Risk communication is described as the process of transmitting information pertaining to specific hazards (EPA (United States Department of Environmental Protection Agency) 2003). It is also an interactive process of exchange of information which informs and/or gathers information from stakeholders on potential hazards (EPA 2003; NRC 1996). The main purpose of risk communication is to provide decision makers with enough information to enable them to make informed decisions about potential risks (Fischhoff 1995; Gibson 1985; Gow and Otway 1990). In addition, risk communication allows for stakeholder involvement during the risk analysis process, increasing the audience trust in risk management programs (EPA 2003; Fischhoff 1990; Gibson 1985; Gow and Otway 1990). Risk communication comprises both written and oral communication practices (Adler and Kranowitz 2005).

Although the importance of communication is generally recognized, the goals and process of risk communication application are less well understood by many governmental agencies (Covello 2004; Covello and Allen 1988; Walls et al. 2004). Possible reasons for this include: reluctance of policy makers to view risk communication as an essential element in the risk analysis process, differences in perception of risk, or simply a lack of awareness of risk communication practices (Covello 2004; Covello and Allen 1988). In addition, governmental agencies often fail to identify economic, social, and political issues related to potential risks (Adler and Kranowitz 2005; Fischhoff 1990). However, governmental agencies have long been concerned with communication methods/tools used to convey information on risks associated with environmental issues, hence their constant efforts to 
evaluate and improve their risk communication efforts (Chess et al. 1995; Covello 2004; Covello and Allen 1988; Sandman 1986; Slovic 1987). From the context of classical biological control, risk communication processes typically include: development and submission of permit applications and environmental assessments (EA) in many countries such as Australia, Canada, New Zealand, Mexico and the United States (US). They also often involve expert groups which provide recommendations, for instance in Australia, Canada, New Zealand, Mexico, and United Kingdom. In some countries such as Australia, New Zealand and the US, the process may also involve formal solicitation of public comments which can be written or open public question and answer sessions (FAO (Food and Agriculture Organization of the United Nations) 2011; Fasham and Trumper 2001; Hunt et al. 2008; Loomans 2007; Mason et al. 2005; REBECA (Regulation of Biological Control Agents) 2006). Mechanisms for exchange of information between governments, the public, stakeholders, and/or scientists can be quite critical for a streamline Pest Risk Analysis (PRA) process, for instance during the submission of applications to National Plant Protection Organizations (Warner and Getz 2008).

The overall goal of this study is to improve the overall risk analysis process for entomophagous BCAs by improving risk communication. We use results from both a survey on risk communication practices used in the US permitting system for approving BCAs and data on operational BCA risk communication frameworks from eight countries. Based on this information, recommendations for improving risk communication practices during the entomophagous BCA permitting process are suggested. It is anticipated that these recommendations will be especially beneficial for countries without an explicit operational risk communication framework.

\section{Materials and methods}

Survey of US risk communication practices

A modification of the "mental models" approach was used to develop a web-based questionnaire. The "mental models" approach, developed by Morgan et al. (2002), identifies gaps and misconceptions on critical problems from both the target audience and the experts, by gathering information from both groups. In our study, the approach involved a series of five steps. First, an expert model describing various relationships between risk assessment, risk management, and risk communication relative to the permitting process of entomophagous BCAs was created (based on a literature survey). Subsequently, the expert model was used to conduct interviews of a small group of knowledgeable stakeholders in order to obtain their opinions on risk communication deficiencies during the permitting process. The third step involved the development of a confirmatory questionnaire (Appendix) which was administered to an expanded group of stakeholders in order to estimate the prevalence of the concerns identified after interviews with stakeholders in step one. As a fourth step, areas were identified in the risk communication framework conducted during the permitting process that needed improvement. The last step in the mental models process which involved the development of an improved risk communication framework and evaluation of its efficiency was not covered in the present study.

A committee comprised of 30 experts were assembled from various agencies and backgrounds, including risk analysts, academic researchers, and members of the private sector. Individuals that were selected had experience and knowledge about the USDAAPHIS-PPQ (US Department of Agriculture-Animal and Plant Health Inspection Service-Plant Protection and Quarantine) permitting process and risk communication procedures. The Dillman method (Dillman 2000) was used to develop and administer a survey of 15 open-ended questions. This method attempts to maximize response rates by minimizing the cost of responding, while establishing trust with the respondents. Open-ended questions were designed to generate perspectives from committee members on the risk communication practices of USDA-APHIS-PPQ and the critical points that should be targeted during the risk communication process. In accordance with the Dillman method, a personalized notice letter was sent to the selected committee members explaining the goals of the study, the reason for their inclusion in the expert committee, and the reason for sending them the questionnaire. Approximately a week later, each participant received the questionnaire with a cover letter. A follow-up notice was sent a week later thanking those participants that had already responded and requesting a response from those who had not yet 
responded. Two weeks later a reminder was sent to non-respondents. Based on the results of the survey, topics and priorities were identified and addressed in a confirmatory questionnaire. A second web-based questionnaire comprised of 18 close-ended questions was developed (Appendix). Each question was reviewed and pre-tested to ascertain its clarity. This study used 18 questions of which 16 were subjected to statistical analysis, and two questions, requesting general information (Questions 1 and 2), were not included in statistical analysis.

A combination of several databases and directories (e.g. Government agency staff, university faculty, and professional societies) were used to compile a list of 500 decision-makers and stakeholders. Different words used during the search for potential respondents included "biological control", "entomology", "regulatory entomology" and "quarantine". A similar modification of the Dillman method (Dillman 2000) was used to administer this larger web-based questionnaire as was used for the smaller group of experts. An introductory electronic message was sent along with the web-based questionnaire. In addition, a note thanking respondents for their participation was automatically sent with the web-questionnaire. An electronic message reminding those who had not responded was sent two weeks later with the electronic link to the web-survey.

Respondents were grouped into five distinct categories based on their affiliation as follows: federal, state, university, non-governmental agency, and private sector. The Kruskal-Wallis test was used to determine whether the distributions of the rating responses were statistically different across the different groups of stakeholders (Sokal and Rohlf 1981).

Review of risk communication frameworks for eight countries

Eight countries with a formalized risk communication system for BCAs were selected for detailed analysis including: Australia, Canada, India, Mexico, New Zealand, Switzerland, United Kingdom and US. Bibliographic databases were used to gather relevant information on the following parameters: format of risk communication messages, modes of distribution of messages, mechanisms used to identify and characterize stakeholders, and tools used to incorporate public involvement during their permitting process of entomophagous BCAs. Published reviews of the organizational structure of National Plant Protection Organizations (NPPOs), Pest Risk Analysis (PRA) process, and permitting system for importation and release for entomophagous BCAs in the Asian-Pacific, North American, and European Union countries were also used as sources of data (FAO 2011; Fasham and Trumper 2001; Hunt et al. 2008; Loomans 2007; Mason et al. 2005; REBECA 2006).

\section{Results}

Survey of US risk communication practices

\section{Response rate and respondent characterization}

Out of the 500 web-based questionnaires sent, 105 participants responded, 29 were undeliverable due to incorrect email addresses, and five opted-out from participating. An adjusted response rate of $23 \%$ was determined. Responses to the web-survey mostly came from participants involved in research $(62 \%$ overall)-92\% of the university group, $57 \%$ of the federal group, and $42 \%$ of the state category. A smaller percentage of the respondents (19\% overall) were involved in regulatory aspects during the implementation of biological control programs ( $24 \%$ of the federal group and $53 \%$ of the state group). Less than $4 \%$ of the overall participants were involved in the commercial production of BCAs (Table 1, Question \#3).

\section{Importance of risk communication}

The majority of respondents across the three major types of affiliations (university researchers, federal employees, and state employees) considered risk communication to be an important component during the permitting process of entomophagous BCAs (Table 1). Participants from the private sector were evenly divided on the importance of risk communication (Table 1, Question \#5).

\section{Risk communication framework}

Four diagrams showing the relationship between risk analysis, risk management, and risk communication were presented in the questionnaire (Fig. 1). In various 
Table 1 Summary of questions and responses from biological control stakeholders divided into four categories

\begin{tabular}{|c|c|c|c|c|}
\hline \multirow{2}{*}{$\begin{array}{l}\text { Question } \\
\text { Question number and } \\
\text { question }\end{array}$} & \multicolumn{4}{|c|}{ Stakeholder categories (Total number, percent of respondents) } \\
\hline & Federal $(42,40 \%)$ & State $(19,18 \%)$ & University $(36,34 \%)$ & Private $(6,6 \%)$ \\
\hline $\begin{array}{l}\text { 3. Biological control area of } \\
\text { involvement }\end{array}$ & $\begin{array}{l}\text { Research }(24,57 \%) \\
\text { Regulation }(10,24 \%) \\
\text { Conservation }(5, \\
11 \%)\end{array}$ & $\begin{array}{l}\text { Research }(8,42 \%) \\
\text { Regulation }(10,53 \%)\end{array}$ & Research $(33,92 \%)$ & $\begin{array}{l}\text { Commercial production } \\
\quad(4,67 \%) \\
\text { Conservation }(1,16 \%) \\
\text { Beneficiary }^{\mathrm{a}}(1,16 \%)\end{array}$ \\
\hline 5. Is $\mathrm{RC}^{\mathrm{b}}$ important? & Yes $(39,93 \%)$ & Yes $(17,90 \%)$ & Yes $(36,100 \%)$ & $\begin{array}{l}\text { Yes }(2,33 \%) \\
\text { No }(2,33 \%)\end{array}$ \\
\hline 7. $\mathrm{RC}$ frequency from $\mathrm{PPQ}^{\mathrm{c}}$ & $\begin{array}{l}\text { At least yearly } \\
(42,100 \%)\end{array}$ & $\begin{array}{l}\text { At least yearly } \\
(19,100 \%)\end{array}$ & $\begin{array}{l}\text { Yearly to never } \\
(33,91 \%)\end{array}$ & $\begin{array}{l}\text { Never } \\
(4,60 \%)\end{array}$ \\
\hline 10. Main RC channels & $\begin{array}{l}\text { Mailed letters } \\
\text { Scientific publications } \\
\text { Scientific conferences } \\
\text { emails }\end{array}$ & $\begin{array}{l}\text { Scientific publications } \\
\text { Scientific conferences }\end{array}$ & $\begin{array}{l}\text { Scientific publications } \\
\text { Scientific conferences } \\
\text { emails }\end{array}$ & $\begin{array}{l}\text { Meetings (lunch, social, } \\
\text { or board) }\end{array}$ \\
\hline $\begin{array}{l}\text { 13. Familiarity with } \\
\text { guidance documents }\end{array}$ & $\begin{array}{l}\text { Somewhat to very } \\
\text { familiar }\end{array}$ & $\begin{array}{l}\text { Somewhat familiar to } \\
\text { familiar }\end{array}$ & $\begin{array}{l}\text { Unfamiliar to } \\
\text { somewhat familiar }\end{array}$ & Unfamiliar \\
\hline $\begin{array}{l}\text { 15. Need for more guidance } \\
\text { documents }\end{array}$ & $\begin{array}{l}\text { Yes, mostly to } \\
\text { definitively }(25 \text {, } \\
60 \%)\end{array}$ & $\begin{array}{l}\text { Yes, somewhat to } \\
\text { mostly }(12,65 \%)\end{array}$ & $\begin{array}{l}\text { Yes, mostly to } \\
\text { definitively }(20 \text {, } \\
56 \%)\end{array}$ & $\begin{array}{l}\text { Yes, definitively } \\
(6,100 \%)\end{array}$ \\
\hline $\begin{array}{l}\text { 16. Does PPQ website } \\
\text { provide enough guidance }\end{array}$ & $\begin{array}{l}\text { Yes, somewhat to } \\
\text { mostly }(23,54 \%)\end{array}$ & $\begin{array}{l}\text { Not at all to yes, } \\
\text { somewhat }(12,65 \%)\end{array}$ & $\begin{array}{l}\text { Yes, somewhat } \\
(24,68 \%)\end{array}$ & $\begin{array}{l}\text { Yes, somewhat } \\
(6,100 \%)\end{array}$ \\
\hline $\begin{array}{l}\text { 17. Knowledge of point of } \\
\text { contacts }\end{array}$ & $\begin{array}{l}\text { Yes, somewhat to } \\
\text { mostly }(24,57 \%)\end{array}$ & $\begin{array}{l}\text { Yes, somewhat to } \\
\text { mostly }(11,59 \%)\end{array}$ & $\begin{array}{l}\text { Yes, somewhat to } \\
\text { mostly }(31,85 \%)\end{array}$ & $\begin{array}{l}\text { Yes, somewhat } \\
(6,100 \%)\end{array}$ \\
\hline $\begin{array}{l}\text { 18. Is public involvement } \\
\text { adequate? }\end{array}$ & $\begin{array}{l}\text { Yes, somewhat to } \\
\text { mostly }(22,53 \%)\end{array}$ & $\begin{array}{l}\text { Not at all to undecided } \\
(10,52 \%)\end{array}$ & $\begin{array}{l}\text { Yes, somewhat to not } \\
\text { at all }(27,74 \%)\end{array}$ & $\begin{array}{l}\text { Yes, somewhat to } \\
\text { undecided }(6,100 \%)\end{array}$ \\
\hline \multicolumn{5}{|c|}{$\begin{array}{l}\text { A fifth category of respondents was identified, but since only } 2 \% \text { of respondents fell in this "Non-governmental" group, they were } \\
\text { not included. Only a portion of the questions in the questionnaire are presented; see "Appendix" for a complete list of questions and } \\
\text { the complete statement of each question }\end{array}$} \\
\hline \multicolumn{5}{|c|}{ a Beneficiary: general public, farmers } \\
\hline b Risk communication & & & & \\
\hline
\end{tabular}

sources of literature (Chartier and Gabler 2001; IPPC 2007), risk communication is integrated within risk analysis, and illustrated as an independent processes interconnected to the risk assessment and risk management elements (model a, Fig. 1). When respondents were asked which of the four diagrams best described existing risk communication practices, $34 \%$ of the overall respondents considered model a to be the best representation. The federal and state groups chose model a (36 and $31 \%$, respectively) or model d (27 and $38 \%$, respectively), whereas the university group selected model a $(33 \%)$ or model b (37\%). Within the private sector category, models $b$ and $d$ received the same level of selection $(50 \%)$.
Frequency, sources, and modes of risk communication

Nearly $80 \%$ of respondents communicated about risks in the context of their profession monthly or more frequently (Fig. 2). Specifically, more than $80 \%$ of researchers across the different types of affiliations communicated at least monthly about risk in the context of their profession. Nearly $70 \%$ of federal and state regulators indicated that they had weekly communications about risk. The risk communication information received by stakeholders was conveyed by the US Plant Protection Organization (USDAAPHIS-PPQ) (30\%), university researchers (29\%), and state and local plant protection agencies (22\%) 
a

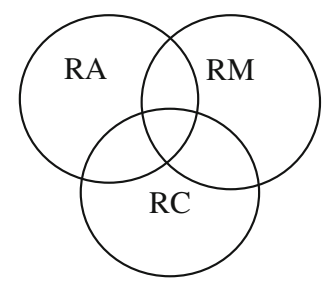

Each component is independent but also interconnected to each others

C

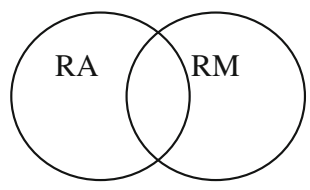

$\mathrm{RA}$ and $\mathrm{RM}$ are

interconnected components and $\mathrm{RC}$ is inexistent b

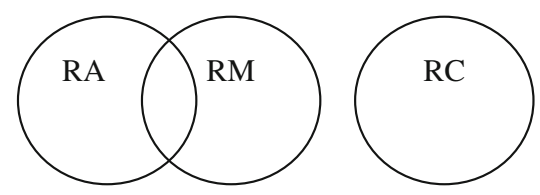

$\mathrm{RA}$ and $\mathrm{RM}$ are

interconnected components and $R C$ is done independently

d

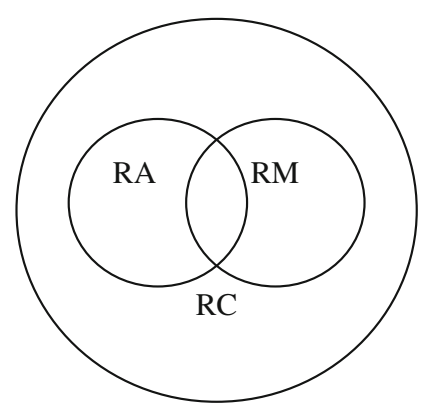

$\mathrm{RC}$ is an intrinsic process of the RA and RM components

Fig. 1 Four model choices (a, b, c, d) of pest risk analysis structure for permitting process of entomophagous biological control agents. $\mathrm{RA}=$ risk analysis, $\mathrm{RM}=$ risk management, $\mathrm{RC}=$ risk communication (Question \# 14 of questionnaire)

Fig. 2 Overall percentage of respondents to questionnaire identifying their frequency of risk communication activities in their profession (Question \# 4 of questionnaire). Error bars denote SE

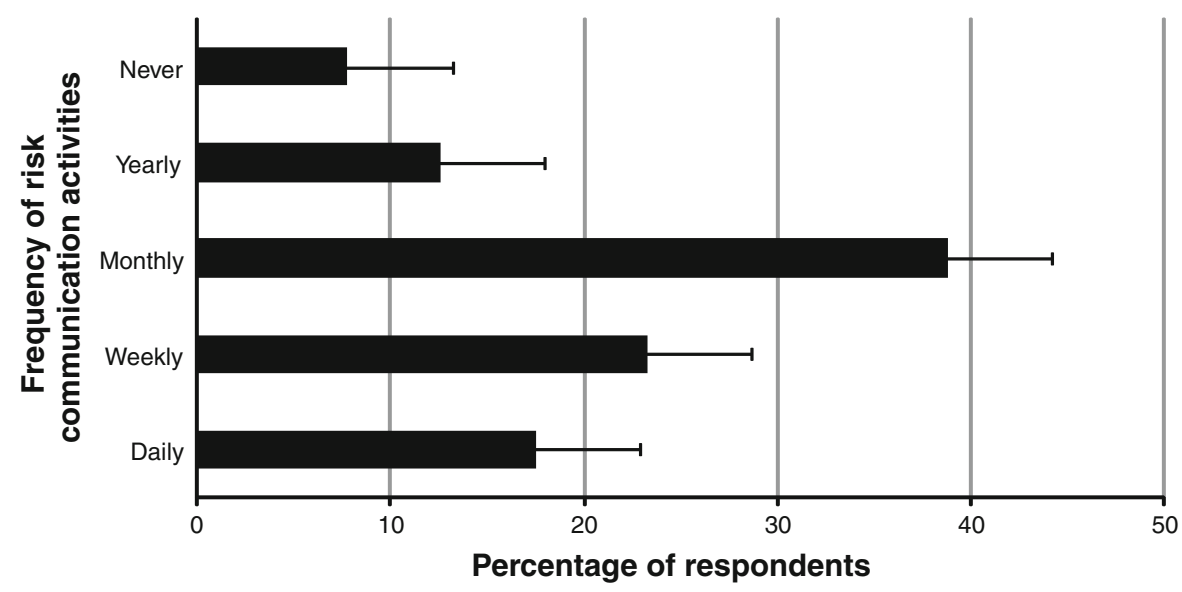

(Fig. 3). The majority of stakeholders received information from USDA-APHIS-PPQ once a year or less frequently (72.6\%) (Table 1, Question \#7). Environmental groups followed by Cooperative Extension Service personnel were less involved in receiving risk communication information $(17 \%$ and $15 \%$ respectively) (Fig. 3). To accomplish their risk communication activities, respondents relied on a combination of traditional modes of communication such as face to face meetings, telephone exchanges, televised programs, pamphlets, scientific publications, and electronic communication channels, such as e-mails, list 


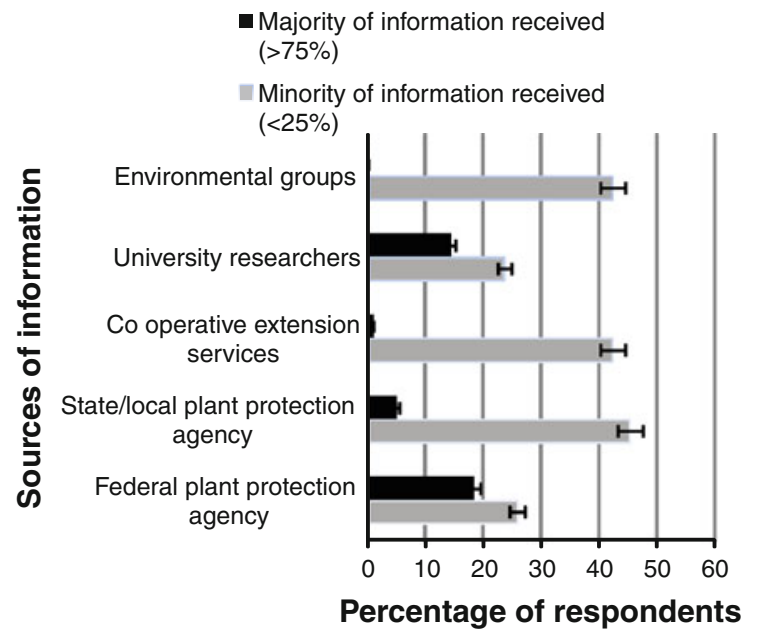

Fig. 3 Overall percentage of respondents to questionnaire identifying their sources of information pertaining to risks associated with importation of biological control agents and their relative importance (Question \# 6 of questionnaire). Error bars denote SE

servers, Federal Registry site, and blogs (Table 1, Question \#10).

\section{Goals of risk communication}

Overall, respondents believed that explaining the risks associated with the importation and release of entomophagous BCAs was the most important goal of risk communication activities (mean score 3.64, Fig. 4).
On the other hand, they also believed that one of the main objectives of these interactions should be to explain the decisions made during the importation of entomophagous BCAs (mean score 3.29, Fig. 4). In decreasing importance, the overall group of respondents considered that the process should encourage good practices among biological control practitioners (mean score 3.06), respond to external peer review recommendations (mean score 2.88), and, with less importance, explain the different petition requirements needed during the importation of the BCAs (mean score 2.13) (Fig. 4). Based on the KruskalWallis test, there was a significant difference in the way the university researchers, federal employees, and state employees ranked the key goals of risk communication $\left(\chi^{2}=12.5 ; 4 \mathrm{df} ; P=0.01\right)$ (Fig. 4).

\section{Respondent satisfaction with risk information and interactions}

Respondents were somewhat familiar with which entities to contact during the permitting process (Table 1, Question \#17). About one-third of participants across the different groups were satisfied with content quality of the risk message (30\%, Fig. 5) and with the risk communication exchanges and interactions (26\%, Fig. 6) they received from USDA-APHISPPQ. When risk communication interactions occurred between USDA-APHIS-PPQ and their stakeholders,

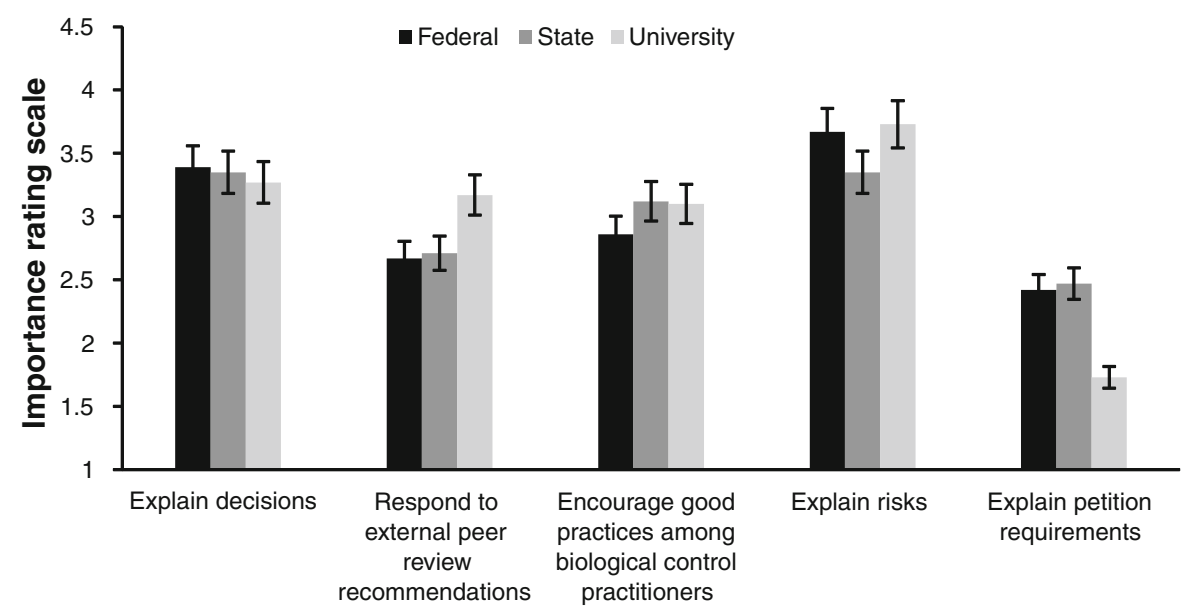

Risk communication goals

Fig. 4 Overall importance rating by questionnaire respondents of five key goals of the risk communication process during the importation of entomophagous biological control agents
( 5 = very important to $1=$ least important) (Question \# 11 of questionnaire). Error bars denote SE 


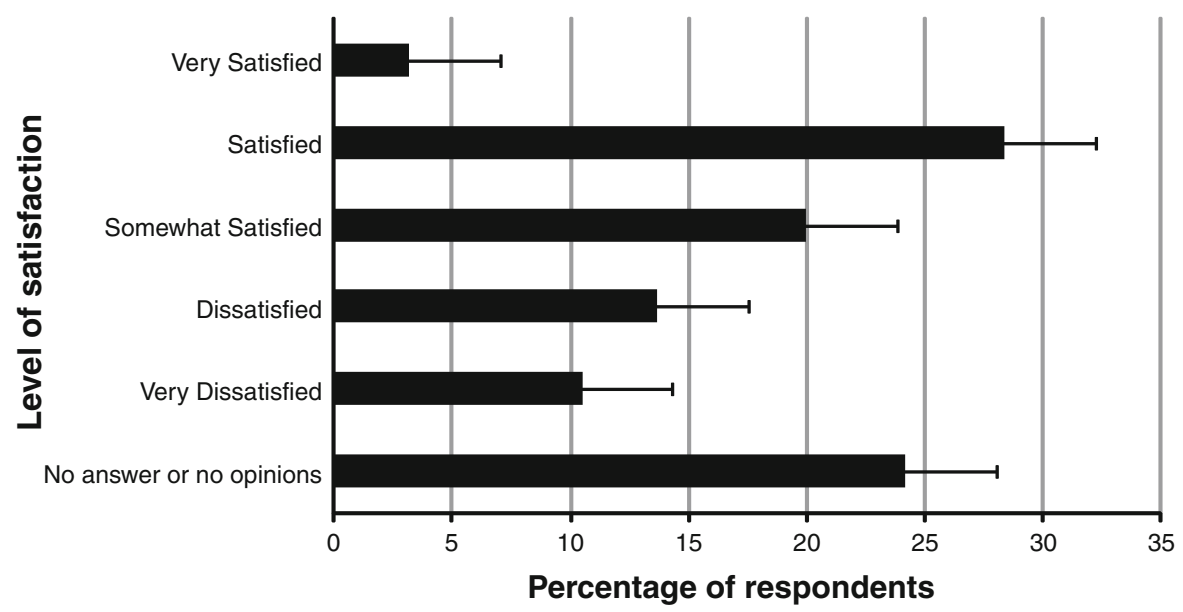

Fig. 5 Overall percentage of questionnaire respondents identifying their level of satisfaction with the risk communication message/information those respondents receive from the US Department of Agriculture, Animal and Plant Health Inspection
Service, Plant Protection and Quarantine pertaining to the importation of entomophagous biological control agents (Question \# 8 of questionnaire). Error bars denote SE

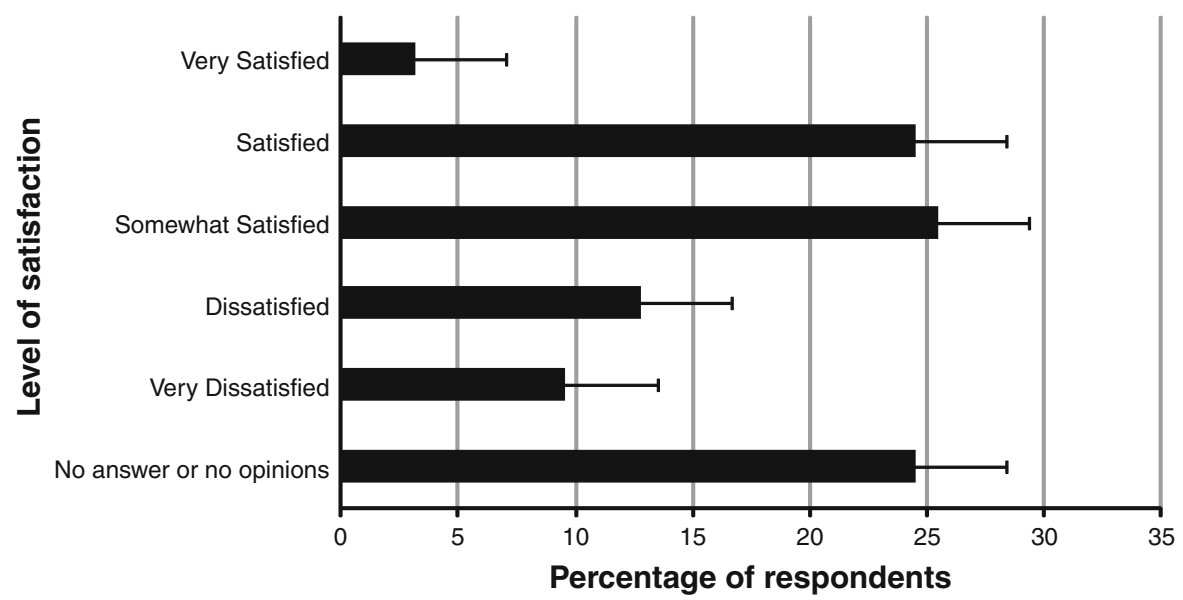

Fig. 6 Overall percentage of questionnaire respondents identifying their level of satisfaction with the risk communication exchanges/interactions those respondents receive from the US Department of Agriculture, Animal and Plant Health Inspection

analysis with Kruskal-Wallis demonstrated that the federal, state, and university groups of respondents ranked the agency's effectiveness in fulfilling risk communication goals the same way $\left(\chi^{2}=5.1 ; 4 \mathrm{df}\right.$; $P=0.3$ ) (Fig. 7). In general, federal, state, and university respondents rated the effectiveness of interactions with USDA-APHIS-PPQ with regards to all five risk communication goals at just above "somewhat effective" (Rating $=2.0$ in Fig. 7). In contrast, the majority ( $60 \%)$ of professionals from the private sector believed the agency to be ineffective in
Service, Plant Protection and Quarantine pertaining to the importation of entomophagous biological control agents (Question \# 9 of questionnaire). Error bars denote SE

explaining the risks pertaining to the importation of entomophagous BCAs.

\section{Need for more guidance documents}

Federal and state groups were somewhat familiar with international and regional standards for phytosanitary measures (ISPM and RSPM, respectively) related to pest risk analysis in general, or specifically to importation and release of entomophagous BCAs (Table 1, Question \#13). Private sector respondents were unfamiliar 


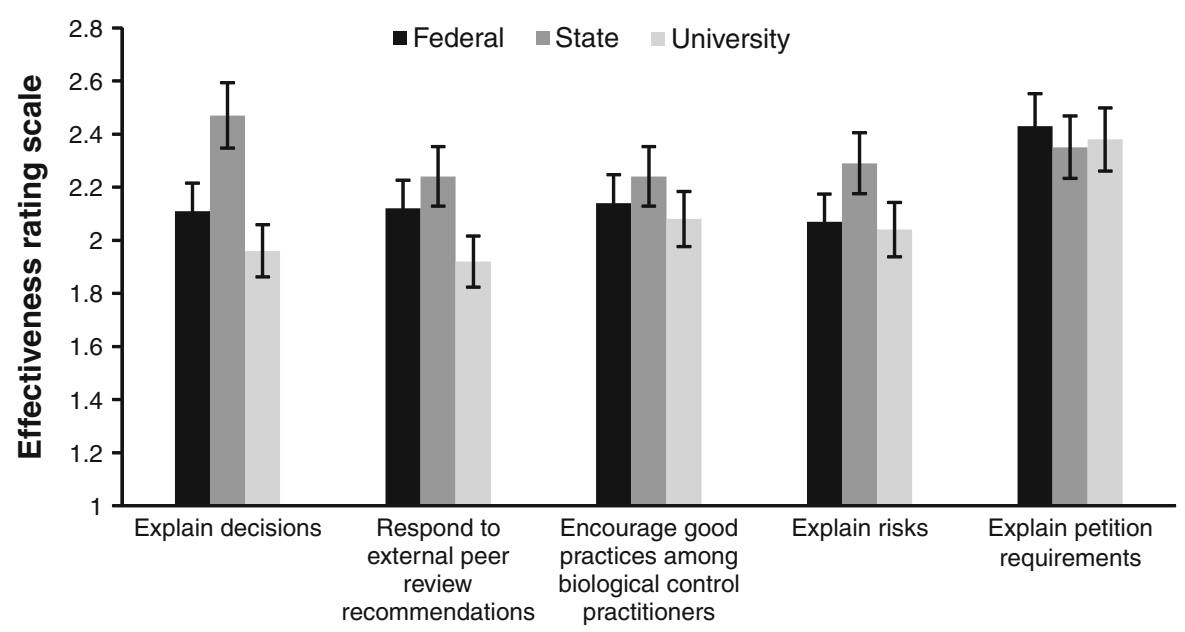

Risk communication goals

Fig. 7 Overall effectiveness rating by questionnaire respondents of the US Department of Agriculture, Animal and Plant Health Inspection Service, Plant Protection and Quarantine in fulfilling each of the five risk communication goals during the

with the various ISPM and RSPM guidance documents (Table 1). Although the USDA-APHIS-PPQ website provides some guidance during the permitting process (Table 1, Question \#16), the respondents recognized a need for more information from USDA-APHIS-PPQ focusing on the risks pertaining to the importation and release of entomophagous BCAs (Table 1, Question \#15).

\section{Public involvement}

Respondents from the state and university groups felt that biological control stakeholders (i.e. general public, expert groups) were not appropriately included during the decision making process of the permitting of entomophagous BCAs (Table 1, Question \#18). Federal and private respondents were more favorable in their impression of adequate public involvement in the permitting process (Table 1, Question \#18).

Review of risk communication frameworks for eight countries

In all eight countries, the decision-making process was based on a risk assessment process which required the applicants to provide a dossier containing information on the entomophagous BCAs being proposed for introduction. The dossier typically included information on importation of entomophagous biological control agents $(4=$ very effective to 1 = ineffective) (Question \# 12 of questionnaire). Error bars denote SE

the identity, biology, ecology, native host range, and distribution of the proposed entomophagous BCAs. All the NPPOs required an evaluation of potential detrimental impacts of a BCA either as part of the dossier or in a separate environmental assessment. All the criteria needed for the development of the dossier were communicated online for most of the selected countries. Assistance was sometimes provided during the development of the dossier. This assistance took several forms such as a toll free hotline number (US), or possibility of consulting with a risk analyst (NZ) before the submission of a permit application. The complete risk assessments developed during the permitting process were sometimes available to the general public for review and comment (Table 2). Seven of the NPPOs used a form of participatory/ collaborative-based risk analysis process which incorporated public opinions during the decision-making process (Table 3 ). Within the PRA process, six countries consulted subject matter experts before approval or rejection of environmental releases of entomophagous BCAs (Table 3). These experts typically represented a wide range of specializations. In addition, three countries solicited public comments prior to making a decision for environmental release of BCAs. One country considered public hearings necessary prior to the importation of entomophagous BCAs (Table 3). 
Table 2 Comparison of communication and reporting processes for pest risk analysis and decision-making during importation and release of entomophagous biological control agents in eight countries (FAO 2011; Fasham and Trumper 2001; FERA 2012; Hunt et al. 2008; Loomans 2007; Mason et al. 2005; PPQS 2006; REBECA 2006)

\begin{tabular}{|c|c|c|c|c|c|c|c|c|}
\hline Issue & $\mathrm{AU}$ & CAN & SW & UK & IN & MX & $\mathrm{NZ}$ & US \\
\hline \multicolumn{9}{|l|}{ Availability of risk assessment guidelines and policies } \\
\hline Required information for applications is available on a website & $\mathrm{X}$ & $\mathrm{X}$ & $X$ & $\mathrm{X}$ & $X$ & $\mathrm{X}$ & $\mathrm{X}$ & $\mathrm{X}$ \\
\hline Risk assessment criteria are publicly available online & & $\mathrm{X}$ & & & & & $\mathrm{X}$ & \\
\hline \multicolumn{9}{|l|}{ Public notifications } \\
\hline Notification of proposed release & $\mathrm{X}$ & $\mathrm{X}$ & & & & & $\mathrm{X}$ & $\mathrm{X}$ \\
\hline Applications provided to general public upon request & & & & $X$ & & & & \\
\hline Risk assessment published in daily newspaper & & & & & & & $\mathrm{X}$ & \\
\hline $\begin{array}{l}\text { Risk assessment posted on National Plant Protection } \\
\text { Organization website }\end{array}$ & $X$ & & & & & & $X$ & $\mathrm{X}$ \\
\hline Risk assessment published in government newsletter & $\mathrm{X}$ & & & & & & $\mathrm{X}$ & $\mathrm{X}$ \\
\hline Community informed about issues relating to safety & $\mathrm{X}$ & & & & $X$ & & & \\
\hline
\end{tabular}

\section{Discussion}

To date, relatively little attention has been given to understanding risk communication activities during Pest Risk Analysis (PRA) in general, and specifically in the context of the permitting process for the importation and release of entomophagous BCAs. Therefore, although risk communication is an important component of the PRA process, it is still an ambiguous concept to many regulatory professionals and their stakeholders (Covello 2004; Walls et al. 2004). Identification of ways to improve risk communication efforts will almost certainly lead to the development of an improved process that will satisfy the needs of stakeholders. The improved process would address some of the key concerns expressed by biological control practitioners, environmental groups, and the general public (Simberloff 2005; Thomas and Willis 1998).

One area that should be clarified is how risk communication is currently integrated within a PRA framework. Although models a or b (Fig. 1) were more frequently chosen by participants (68.2\%), various scientific publications and many respondents indicated that model d (Fig. 1) best described how risk communication should be integrated. In model d, risk communication is an integral element of risk assessment and management components within the PRA. The difference in opinions of respondents between what is the current practice and what should be targeted demonstrated a flaw in the current risk communication framework. Model d should form a basis for a more participatory based PRA model as observed in Australia and New Zealand. Consultations with general public, and/or experts in the subject matter during the permitting process for BCAs will provide an additional source of knowledge to validate the identification of risk factors and management options.

Although one of the concerns of many NPPOs, such as USDA-APHIS-PPQ, is to increase public involvement in the decision making process (APHIS (Animal Plant Health and Inspection Service) 2009), there is also a lack of information on risk communication activities that could be used to increase stakeholders' participation. Previous studies showed that stakeholders had little knowledge of the risk analysis framework pertaining to the importation and release of entomophagous BCAs, consequently limiting their participation (APHIS 1996, 2006, 2007). Development of practical mechanisms, such as public notifications in newspapers, direct mail, or email alerts as implemented by USDA-APHIS-PPQ will increase all stakeholders' awareness of the PRA process. Understanding of PRA and risk communication frameworks will also be increased by presenting the information in different formats (i.e. internet, brochures, newspapers, relevant guidelines/standards). Development of links pertaining to subject matter on NPPOs websites as has been done by the NZ Plant Protection Organization will provide additional guidance. In addition, when absent, mechanisms for public involvement, such as public hearings, should be clearly integrated within the PRA processes. 
Table 3 Comparison of reviewing and consultation processes for pest risk analysis and decision-making during permitting process for entomophagous biological control agents in eight countries (FAO 2011; Fasham and Trumper 2001; FERA 2012; Hunt et al. 2008; Loomans 2007; Mason et al. 2005; PPQS 2006; REBECA 2006)

\begin{tabular}{|c|c|c|c|c|c|c|c|c|}
\hline Processes & AU & CAN & SW & UK & IN & MX & NZ & US \\
\hline \multicolumn{9}{|l|}{ Public participation } \\
\hline Solicit public comments in the decision process prior to importation & $\mathrm{X}$ & & & & & & & \\
\hline Solicit public comments in the decision process prior to release & $X$ & & & & & & $\mathrm{X}$ & $\mathrm{X}$ \\
\hline Formal procedures in place for hearings during decision process & & & & & & & $X$ & \\
\hline Approval process includes public comment periods & $\mathrm{X}$ & & & & & & $X$ & $X$ \\
\hline \multicolumn{9}{|l|}{ Use of secondary sources } \\
\hline Use of risk assessments from foreign countries & $X$ & & & & & & & \\
\hline Use data or results from previously submitted risk assessments & $\mathrm{X}$ & & & & & & & \\
\hline \multicolumn{9}{|l|}{ Use of experts } \\
\hline Consultation with scientific experts & $\mathrm{X}$ & $X$ & & $\mathrm{X}$ & $\mathrm{X}$ & $X$ & $X$ & \\
\hline Consultation with members of regulatory body & $\mathrm{X}$ & $\mathrm{X}$ & & $\mathrm{X}$ & $\mathrm{X}$ & $\mathrm{X}$ & $\mathrm{X}$ & $\mathrm{X}$ \\
\hline
\end{tabular}

The present study showed that stakeholders' perception and understanding of the communication channels used, and the efficiency of the risk message needs to be improved in order to increase participation by stakeholders. In addition, the survey showed that stakeholders received information from only a few sources and very infrequently. The majority of the stakeholders felt that the USDA-APHIS-PPQ website was somewhat efficient at providing enough guidance but only $1 \%$ of the respondents thought that the website definitely offered sufficient guidance. It seems that USDA-APHIS-PPQ is aware of these issues because, in November 2009, the Agency conducted a survey of their registered stakeholders to obtain feedback on how they could improve the overall delivery of information on their website. The development of website links about critical issues relating to PRA will provide improved information and guidance to stakeholders. Our study showed that various modes of distribution of risk messages should be investigated to increase stakeholder access to risk related information. This includes television, national public radio, and/or newspaper announcements and programs on the communication of risk but also novel modes of distribution such as e-alerts, text messages, facebook pages, and blogs. In New Zealand, risk assessment summaries are posted on the government website, newsletters, and daily papers.

Even when stakeholders received information from USDA-APHIS-PPQ, this message did not always meet their needs. For instance, the majority of respondents from the private sector said that USDA-APHIS-PPQ was ineffective in communicating risk pertaining to the importation and release of entomophagous BCAs. The difficulty faced by USDA-APHIS-PPQ in fulfilling stakeholder needs may come from the fact that the different groups of stakeholders view risk communication goals differently (Fig. 4). Therefore, there is a need to identify the main goals of the risk communication efforts, specific to the different types of stakeholders, and respond accordingly. Surveys, public meetings, and training workshops are tools that can be used to identify stakeholders and develop risk messages accordingly to their needs.

A majority of the stakeholders were less than satisfied with the quality of risk communications, the communication messages, or the risk message exchanges and interactions from USDA-APHIS-PPQ (Fig. 5). For instance, $60 \%$ of respondents from the private sector were either dissatisfied to very dissatisfied with the risk communication messages and interaction with USDA-APHIS-PPQ (Fig. 6). This level of dissatisfaction confirmed the negative perception of USDA-APHIS-PPQ's customer service record from their stakeholders as illustrated by Warner and Getz (2008). A greater involvement in the decision making process by stakeholders and expert peer review groups may increase the stakeholders' trust in the decisions and improve the stakeholders' perception of the quality of the risk communication message. Therefore, a clear framework, such as online solicitations of public comments or public hearings as 
implemented in New Zealand, which explained how public concerns will be integrated during decision making process, should be implemented. In October 2009, a proposed rule was submitted by USDAAPHIS-PPQ for the mandatory development of an Environmental Impact Statement (EIS) before the importation of entomophagous BCAs proposed for research and release (APHIS 2009). Under the National Environmental Policy Act (NEPA), the development and submission of an EIS or EA is required when a proposed action, such as the introduction of any non-native organism, has potentially significant environmental impacts (Kubasek and Silverman 2005). An external group of experts selected by the governmental agency reviews the EA. The group of experts then provides an analysis of potential adverse environmental effects of the proposed action. In accordance with the Administrative Procedure Act's rules on informal rule making, a draft is published in the Federal Register and public comments are accepted by the stakeholders for a period of 60 days. One of the major advantages of this process is that it requires public participation in the decisionmaking process (Kubasek and Silverman 2005). Similarly, public comments are also solicited before importation and/or environmental release of entomophagous BCAs in Australia. In addition, a direct line of contacts for the different governmental agencies involved in the decision making process as illustrated in the Indian PRA system will reduce the possibility of mixed messages.

The results from the review and the web-survey provided baseline data to analyze risk communication activities during the importation and release of entomophagous BCAs. Based on the findings of this study, the following recommendations are suggested as a means to enhance risk communication frameworks during the PRA process for BCAs:

- Increase the transfer of information pertaining to the PRA process of entomophagous BCAs by presenting information in different formats and using novel modes of distribution.

- Characterization of target audience and risk communication goals through workshops/trainings.

- Careful identification and development of risk communication messages specific to different types of stakeholders.

- Greater involvement of governmental agencies in stakeholders' education about PRAs.

- Development of PRA frameworks which will increase stakeholder involvement in the decisionmaking process.

- Consistency in risk communication messages conveyed by federal, state, and local agencies.

Since many countries are increasingly interested in developing and/or enhancing their existing processes for the importation and release of biological control agents (Kairo et al. 2003), it is anticipated that these recommendations will also be useful in such situations.

Acknowledgments The authors would like to thanks Stephanie Bloem for helpful comments and recommendations during the study. Earlier versions of this manuscript were improved by Robert Flanders, Erich Rudyj, and Keith Warner and two anonymous reviewers. This work is funded under the FAMU/USDA-APHIS Cooperative Agreement 07-10-81000755-CA.

\section{Appendix}

See Table 4.

Table 4 Questionnaire

\begin{tabular}{ll}
\hline $\begin{array}{l}\text { Question } \\
\text { Number }\end{array}$ & Question \\
\hline 1. & About Yourself \\
2. & In which group will you categorize yourself? \\
3. & How would you categorize your involvement in biological control? \\
4. & How often do you communicate risk in the context of your profession? \\
5. & Do you view risk communication as an important component during the importation process of entomophagous \\
& BCAs ${ }^{\text {a }}$.
\end{tabular}


Table 4 continued

Question Question

Number

6. From which entity(ies) do you receive information pertaining to risks associated with importation of BCAs and what is relative importance of each source?

7.

How often do you receive information about risks associated with the importation of entomophagous BCAs from USDA-APHIS-PPQ ${ }^{b}$

8.

How would you rate your level of satisfaction with the risk communication information that you perceive from USDA-APHIS-PPQ pertaining to the importation of entomophagous BCAs?

9.

How would you rate your level of satisfaction of the Risk Communication interactions with USDA-APHIS-PPQ concerning the importation of entomophagous BCAs?

10. What percentage best describes the communication channel(s) through which you receive the information on risks pertaining to the importation of entomophagous BCAs?

11. Rank the following key goals of the risk communication process during the importation of entomophagous BCAs in order of importance

12. How effective is USDA-APHIS-PPQ in fulfilling each risk communication goal during the importation of entomophagous BCAs?

13. What is your degree familiarity with the different guidance documents pertaining to the importation of entomophagous BCAs?

14. Which of these models best represent your perception of risk communication as it is currently incorporated during the importation process of entomophagous BCAs

15. Do you think there is a need for more guidance documents from USDA-APHIS-PPQ concerning the importation of entomophagous BCAs?

16. Does your USDA-APHIS-PPQ website provide you with enough explanations and guidance about importation of entomophagous BCAs?

17. Do you have the information (phone numbers, emails, fax number, address) of points of contact that you can reach if you have any questions during the importation of entomophagous BCAs process?

18.

In your opinion, is the public adequately involved in the importation of entomophagous BCAs process?

${ }^{a}$ Biological Control Agents

${ }^{\mathrm{b}}$ US Department of Agriculture-Animal and Plant Health Inspection Service-Plant Protection and Quarantine

\section{References}

Adler P, Kranowitz J (2005) A primer on perceptions of risk, risk communication and building trust. National Energy Technology Laboratory, US Department of Energy, USA

APHIS (Animal Plant Health and Inspection Service) (1996) Options for changes in biological control regulations and guidelines in the United States: a Strawman for comment. National Biological Control Institute, Riverdale, USA

APHIS (Animal Plant Health and Inspection Service) (2006) Plant protection and quarantine permitting review highlights, DA2006-04. Available online. http://ipm.ifas.ufl.edu/pdf/Organisms PermittingReview.pdf. Accessed 15 Dec 2010

APHIS (Animal Plant Health and Inspection Service) (2007) Import and export. Available online. http://www.aphis.usda.gov/ import_export/index.shtml. Accessed 15 Dec 2010

APHIS (Animal Plant Health and Inspection Service) (2009) Environmental impact statement; movement of plant pests, biological control organisms, and associated articles. Federal Register (7CFR Part 330), Docket No. Aphis2008-0076 74: 53673-53674

AQIS (Australia Quarantine Inspection Service) (1997) Protocol for biological control agents. Available online. http:// www.daff.gov.au/ba/reviews/biological_control_agents/ protocol_for_biological_control_agents. Accessed 16 Apr 2012

Barratt BIP, Moeed A (2005) Environmental safety of biological control: policy and practice in New Zealand. Biol Control 35:247-252

Chartier J, Gabler S (2001) Risk communication and government: theory and application for the Canadian food and inspection agency. Canadian food and inspection agency public and regulatory affairs branch, Canada

Chess C, Salomone KL, Hance BJ (1995) Improving risk communication in government: research priorities. Risk Anal 15:127-135

Covello VT (2004) Effective risk communication: the role of government and non-governmental organizations. Springer

Covello V, Allen F (1988) Seven cardinal rules of risk communication. Environmental Protection Agency, Office of Policy Analysis, Washington, DC, USA

Dillman DA (2000) Mail and internet surveys, the tailored design method. Wiley, New York, USA

EPA (United States Department of Environmental Protection Agency) (2003) Considerations in risk communication-a digest of risk communication as a management tool. 
Technology Transfer and Support Division, National Risk Management Research Laboratory Office of Research and Development, US Environmental Protection Agency, Cincinnati, USA

ERMA (Environmental Risk Management Authority) (2012) New organisms. Available online. http://www.epa.govt.nz/ new-organisms/Pages/default.aspx. Accessed 16 Apr 2012

FAO (Food and Agriculture Organization of the United Nations) (2011) Plant protection profiles from Asia-Pacific countries (2009-2010). FAO Regional Office for Asia and the Pacific (RAP) Publication, Bangkok, Thailand

Fasham M, Trumper K (2001) Review of non-native species legislation and guidance. Ecoscope, St Ives, UK

FERA (The Food and Environmental Research Agency) (2012) The regulation and control of the release of non-native animals and plants into the wild in Great Britain. Available online http://www.fera.defra.gov.uk/wildlife/ecologyMan agement/documents/wcaCompleteGuide.pdf. Accessed 05 Jan 2012

Fischhoff B (1990) Psychology and public policy: tool or tool maker? Am Psychol 45:57-63

Fischhoff B (1995) Risk perception and communication unplugged: twenty years of process. Risk Anal 15:137-145

Gibson M (1985) To breathe freely: risk, consent, and air. Rowman and Allanheld, Totowa, USA

Gow HB, Otway H (1990) Communicating with the public about major accidents hazard. Gow HB, Otway H (eds). Elsevier, London, UK

Hunt EJ, Kuhlmann U, Sheppard A, Qin TK, Barratt BIP, Harrisson L, Mason PG, Parker D, Flanders RV, Goolsby J (2008) Review of invertebrate biological control agent regulation in Australia, New Zealand, Canada and the USA: recommendations for harmonized European system. J App Entomol 132:89-123

IPPC (International Plant Protection Convention) (2004) Pest risk analysis for quarantine pests including analysis of environmental risks and living modified organisms. International Standards for Phytosanitary Measures \# 11, International Plant Protection Convention, United Nations Food and Agriculture Organization, Rome, Italy. Available online. https://www.ippc.int/index.php?id=1110798\&from page $=13399 \&$ tx_publication_pi 1 [showUid] $=34163 \&$ type $=$ publication $\& \mathrm{~L}=0$. Accessed 16 Apr 2012

IPPC (International Plant Protection Convention) (2005) Guidelines for the export, shipment, import and release of biological control agents and other beneficial organisms. International Standards for Phytosanitary Measures \# 3, International Plant Protection Convention, United Nations Food and Agriculture Organization, Rome, Italy. Available online. https://www.ippc.int/file_uploaded/1323944456 ISPM_03_2003_En_2011-12-01_Refor.pdf. Accessed 15 Dec 2011

IPPC (International Plant Protection Convention) (2007) Framework for pest risk analysis. International Standards for Phytosanitary Measures \# 2, International Plant Protection Convention, United Nations Food and Agriculture Organization, Rome, Italy. Available online. https://www. ippc.int/file_uploaded/1323944382_ISPM_02_2007_En_ 2011-12-01_Refor.pdf. Accessed 15 Dec 2011
IRA (Import Risk Analysis) (2007) Import risk analysis handbook. Available online. http://www.daff.gov.au/ba/ira/ process-handbook. Accessed 24 March 2011

Kairo MTK, Cock JW, Quinlan MM (2003) An assessment of the use of the code of conduct for the import and release of exotic biological control agents (ISPM \# 3) since its endorsement as an international standard. BioControl News Info $24: 15 \mathrm{~N}-27 \mathrm{~N}$

Kubasek NK, Silverman GS (2005) Environmental law. Pearson Education Inc, Upper Saddle River, USA

Loomans AMJ (2007) Regulation of biological control agents in Europe: review and recommendations in its pursuit of a harmonized system. In: Report REBECA (Regulation of Biological Control Agents). Available online. http://www. rebeca-net.de/downloads/Regulation\%20of\%20Beneficials \%20in\%20Europe.pdf. Accessed 01 April 2011

Mason PG, Flanders RG, Arrendondo-Bernal HA (2005) How can legislation facilitate the use of biological control of arthropods in North America. Proc 2nd Int Symp Biol Control of Arthropods, Davos, Switzerland, 12-16 September 2005, pp 701-714

Morgan MG, Fischhoff B, Bostrom A, Atman CJ (2002) Risk communication: a mental models approach. Cambridge University Press, New York, USA

NAPPO (North American Plant Protection Organization) (2008) Guidelines for petition for first release of exotic entomophagous biological control agents. Regional Standards for Phytosanitary Measures \# 12. Available online. http:// www.nappo.org/en/data/files/download/PDF/RSPM12-Rev2010-08-e.pdf. Accessed 12 Dec 2010

National Research Council NRC (1996) Understanding risk: informing decision in a democratic society. National Academy Press, Washington, DC, USA

PPQS (Plant Protection Quarantine and Storage) (2006) Guidelines for regulating export, import and release of biological control agents and other beneficial organisms. Available online. http://plantquarantineindia.org/pdffiles/ guidlelinesforbeneficial\%20organisms_7AUG2006.pdf. Accessed 05 Jan 2011

REBECA (Regulation of Biological Control Agents) (2006) General topics. In: Final report-regulation of biological control agents-specific support action, sustainable management of Europe's natural resources

Sandman PM (1986) Explaining environmental risk. Environmental Protection Agency, Office of Toxic Substances. Washington, DC, USA

Simberloff D (2005) The politics of assessing risk for biological invasions: the USA as a case study. Trends Ecol Evol 20: 216-222

Simberloff D, Stiling P (1996) Risks of species introduced for biological control. Biol Conserv 78:185-192

Slovic P (1987) Perception of risk. Science 236:280-285

Sokal RR, Rohlf FJ (1981) Kruskal-Wallis. In: Wilson J, Cotter S (eds), Biometry. WH. Freeman and Co. New York, USA, pp 429-432

Thomas MB, Willis AJ (1998) BioControl-risky but necessary? Trends Ecol Evol 13:325-329

van Lenteren JC, Bale F, Bigler F, Hokkanen HMT, Loomans AJM (2006) Assessing risks of releasing exotic biological 
control agents of arthropod pests. Ann Rev Entomol 51:609-634

Walls J, Pidgeon N, Weyman A, Horlick-Jones T (2004) Critical trust: understanding lay perceptions of health and safety risk regulation. Health Risk Soc 6:133-150

Warner KD, Getz C (2008) A socio-economic analysis of the North American commercial natural enemy industry and implications for augmentative biological control. Biol Control 45:1-10

\section{Author Biographies}

Oulimathe Paraiso is a research associate at the Center for Biological Control at Florida A\&M University. This study is part of a Ph.D. project focusing on risk communication procedures during the permitting process of entomophagous biological control agents.

Moses T. K. Kairo is the director of the Center for Biological Control at Florida A\&M University. His research interests focus in areas of classical and augmentative biological control.

Stephen D. Hight has nearly 25 years experience in biological control and has been a research entomologist with USDA-ARS for the past ten years. He has conducted research in various aspects of biological control.

Norman C. Leppla is a professor at University of Florida and the program director of IPM Florida. He established the first laboratory specifically designed to support the commercial production of natural enemies industry in the US.

James P. Cuda is a professor at University of Florida associated with the Center for Aquatic and Invasive Plants. His research interests include improving methods for the screening and evaluation of biological control agents of invasive weeds.

Marcia Owens is an environmental attorney and a professor at Florida A\&M University. She also serves on the Board of the North American Association for Environmental Education.

Michael T. Olexa is a professor at the Food and Resource Economics Department at University of Florida and the director of the UF/IFAS Agricultural Law Center. His specialization is in agricultural and natural resource law. 